\title{
How do private entrepreneurs transform local social capital into economic capital? Four case studies from rural Denmark
}

\author{
Gunnar Lind Haase Svendsen ${ }^{\mathrm{a}, *}$, Chris Kjeldsen ${ }^{\mathrm{b}}$, Egon Noe ${ }^{\mathrm{b}}$ \\ a University of Southern Denmark, Center of Rural Research, Niels Bohrs Vej 9, DK-6700 Esbjerg, Denmark \\ b Aarhus University, Faculty of Agricultural Sciences, Denmark
}

\section{A R T I C L E I N F O}

\section{Article history:}

Received 26 August 2009

Received in revised form 5 May 2010

Accepted 21 June 2010

\section{JEL classification:}

D01

D23

D24

D85

Keywords:

Forms of capital

Social capital

Economic capital

Private entrepreneurs

Local communities

Repeated Prisoner's Dilemma game

Rural Denmark

Bourdieu

\begin{abstract}
A B S T R A C T
Bourdieu's (1986) General Theory of the Economy of Practices assumes that people perpetually transform tangible and intangible forms of capital according to certain 'laws of conversion'. On this background, and combining sociology and micro-economics, we analyze specific strings of capital conversion in time and space. More specifically, we raise the question: How do private entrepreneurs transform local social capital into economic capital? We combine in-depth interviews with four private entrepreneurs in rural Denmark with Prisoner's Dilemma game theory. Thus each of our cases illustrates one of the outcomes in the PD matrix. In this way we explain why only one of the four entrepreneurs succeeds in capitalizing social capital.
\end{abstract}

(c) 2010 Elsevier Inc. All rights reserved.
"It's fun to be the sucker - If you can afford it" (John Steinbeck, Sweet Thursday, p. 20).

\section{Introduction}

In economic sociology, Bourdieu's neo-capital theory (Bourdieu, 1986) has regularly been applied by sociologists eager to reject the rational action theory (Anheier et al., 1995). Similarly, sociologists have worried about political scientists and economists monopolizing the popular concept of 'social capital' - broadly defined as network cooperation based on trust and regular face-to-face interaction - and including it in the neoclassical economic vocabulary.

We however find it fruitful to unite the Bourdieusian and rational action approaches. In this way, we abstain from choosing between an exogenous approach (cultural-historical constructions) and an endogenous approach (universal human mind) (cf. Jackman and Miller, 1998). Rather we seek to analyze complex capital conversion within a rational action framework, that is, within specific games.

\footnotetext{
* Corresponding author. Tel.: +45 6550 4227; fax: +45 65501091.

E-mail address: glhs@sam.sdu.dk (G.L. Haase Svendsen).
}

Following Bourdieu, it is not erroneous to claim that individual agents are simultaneously driven by genuine (altruistic) interests by him termed social libido - and pure (utilitarian) self-interest. There is simply no such clear cut between non-economic and economic purposes. Human action is per se socioeconomic. Thus, according to Bourdieu people exchange tangible and intangible resources in a social world that is near empty of a one-dimensional Economic Man. An intellectual invention (or monster), who should he or she actually exist - would totally fail to participate in a socially constructed passion play, an illusio, and therefore would be an incredibly lonesome and unhappy stranger in this world, like the misers in Dickens' literary universe.

Methodologically, we think that the laws of conversion (Bourdieu, 1986, pp. 252-255) can best be observed at the microlevel, by analyzing specific strings of capital conversion in time and space done by concrete persons. Therefore, in the following we draw on in-depth interviews with four private entrepreneurs in rural Denmark, in an attempt to go deep into their biographies in order to grasp their whole worldviews. Our key contribution is to combine this qualitative 'bottom-up' methodology with a rational action framework from micro-economics, namely Prisoner's Dilemma game theory, illustrating each of the four pay-off outcomes in the matrix with 'flesh and blood' so to speak. 
Indeed, we think the combination of Bourdieu's capital theory and game theory is appropriate. Bourdieu himself often used the 'game' metaphor - for example actors playing cards, some having better cards than others (quantity and quality of their capital stock) and others playing their cards better than others - stressing that each game always is a historically constructed social game.

Our overall question, then, becomes: How do private entrepreneurs transform local social capital into economic capital?

We try to answer this question by analyzing capital accumulation and conversion in situ, that is, following concrete actors within specific time-space contexts (Svendsen, 2006). This means that we abandon an often used 'one-capital' approach, implying a onesided focus on either physical, economic, human, cultural or social capital, and instead include many forms of tangible/intangible capital that are inextricably intertwined and mutually convertible (cf. Waldstrøm and Svendsen, 2008). This takes place in repeated games of long duration (10-15 years) where an entrepreneur strives to obtain win-win cooperation with other entrepreneurs in a local area, evaluating the pay-off obtained after each round. This however with varying success and strongly contingent upon incentive structure and the overall socio-cultural context, including, e.g. degree of obligations of reciprocity among players, local traditions, personal acquaintance, inter-personal trust and the range of possibilities to punish free-riders (Herreros, 2004, 44ff; Poulsen, 2009, 40ff).

In such specific time-space contexts, a person's 'credentials' appear particularly important for economic success, in the form of possession of a harmonious mix of tangible and intangible capital (e.g. tools, skills, money, connections, social networks) that function as a credit in the broadest sense of the word - that is, giving access to more capital, which hitherto has been out of reach for the entrepreneur in question. In line with our findings, it is probable that social capital here should be seen as a 'master capital' as, without this capital form, it simply becomes impossible to get access to all the other capitals and, ultimately, to credibility and credit in the local area.

Seen from the perspective of the individual entrepreneur, then, accumulating capital becomes synonymous with getting access to capital through local networks - that is to say, if networking with other local entrepreneurs pays the individual entrepreneur (rather than, say, cultivate national or international networks). However, if cooperation is non-productive or even counter-productive for the entrepreneur, due to various cooperative barriers including culture, communication, individual traits, degree of personal knowledge, level of trust, etc., the entrepreneur's costs (time spending, work and money) will exceed the profits he can obtain, and he will ultimately be tempted to defect. Thus the game ends up in a Nash equilibrium where all players' dominant strategy is non-cooperation in a lose-lose game, that is, what in behavioral economics has been regarded as the most dominant strategy, meaning a strategy that "produces better results no matter what strategy the opposing player follows" (Frank, 2006, p. 455). Using iterated game theory, we have chosen four cases that may well illustrate four typical outcomes for rural entrepreneurs investing in local networks over a fairly long period of time (5-10 years).

\section{Theory and models}

In the following, we present Bourdieusian neo-capital theory, as well as compare it with 'old' capital theory. This leads to a listing of the main characteristics of 'capital', i.e. a taxonomy. Then a social capital taxonomy is proposed, followed by the PD model.

\subsection{Bourdieu and neo-capital theory}

Bourdieu's forms of capital were placed in a completely new framework, compared to traditional economics. We might term

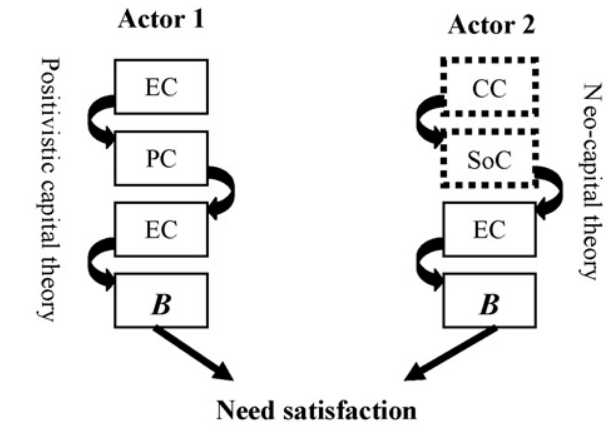

Explanation:

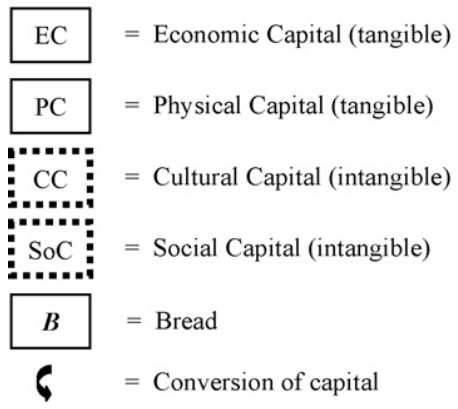

Fig. 1. Conversions of capital: two lines of conversion.

this framework neo-capital theory - that is a theory aimed to break with formerly positivistic capital theory (Waldstrøm and Svendsen, 2008). Bourdieu's theory, termed a General Theory of the Economy of Practices, asserts that power relations are determined by the unequal distribution of capital among social groups and individuals (Bourdieu, 1984, 1986). Furthermore, both tangible and intangible capital (e.g. physical, economic, social, cultural, symbolic) are being perpetually accumulated and converted by individuals in social 'games'.

Fig. 1 illustrates the main differences between 'old' and 'new' capital theory. In the positivistic model (actor 1 to the left), only tangible forms of capital are converted by the actor, resulting in need satisfaction in the form of buying a bread. In contrast, in the arguably more realistic neo-capital or Bourdieusian model (actor 2 to the right) both intangible and tangible forms of capital are converted by the actor in order to get his bread. Say, he uses his cultural capital (knowledge of cultural codes) to build networks (social capital), which then give access to a job and earnings (economic capital), which finally makes him able to buy a bread.

Following Bourdieu, forms of capital are powerful - indeed, they are near identical with power (Bourdieu, 1986, p. 243). If a person or a group succeeds in accumulating the right mix of capital, he/they can simply rule their surroundings. This is because the various forms of capital are accumulated, historical labor (labor-time) in either materialized or incorporated form.

In Table 1, we have listed 10 properties characterizing forms of capital, where the first one is taken from old capital theory, while the 9 others are deducted from the works of Bourdieu $(1986,1989)$.

As is shown in Table 1, forms of capital are productive for the single actor, who gets economic profits from them, cf. Adam Smith's seminal definition: "A wealth that accrues its owner revenues" without being destroyed itself. They are mutually convertible, i.e. one form of capital (e.g. human) can be converted into another (e.g. economic) at a certain transaction cost, including a certain amount of transfer labor-time invested by a person; transmissible in either materialized or incorporated form, as tangibles or intangibles. Further, they are capitalizable, i.e. can all immediately be converted into the most liquid capital, economic capital (money, 


\section{دريافت فورى ـ ـ متن كامل مقاله}

\section{ISIArticles}

مرجع مقالات تخصصى ايران

ل امكان دانلود نسخه تمام متن مقالات انكليسى ل امكان دانلود نسخه ترجمه شده مقالات ل يذيرش سفارش ترجمه تخصصى $\checkmark$ ل امكان جستجو در آرشيو جامعى از صدها موضوع و هزاران مقاله ل امكان دانلود رايكان r صفحه اول هر مقاله

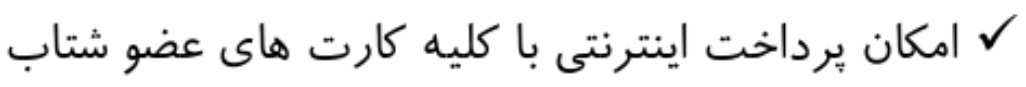
ل دانلود فورى مقاله پِ از برداخت آنلاين

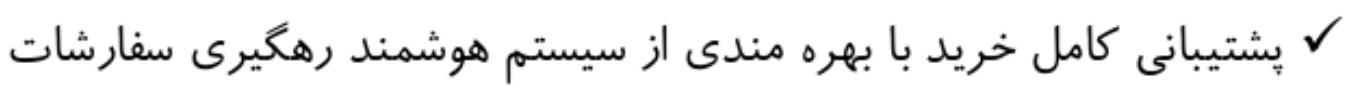

